\title{
Peningkatan Hasil Tanaman Okra Dengan Pemberian Pupuk Kompos dan NPK
}

\author{
Made Sri Yuliartini, Ketut Agung Sudewa, Luh Kartini, Ersa Remi Praing \\ Program Studi Agroteknologi, Fakultas Pertanian, Universitas Warmadewa \\ E-mail: yuliartinisri@yahoo.co.id ; agsudewa63@gmail.com
}

\begin{abstract}
The purpose of this research is to determine the effect of compost and NPK Phonska fertilizer application to the growth and yield of okra plants, and to get optimum dose. This research was conducted in experimental garden of Agricultural Faculty of Warmadewa University. The design used in this research is factorial randomized block design (RAK) consisting of two treatments: compost fertilizer and NPK Phonska fertilizer. The interaction treatment between doses of compost fertilizer with NPK Phosnka and single treatment of NPK Phonska have no significant effect on all observed variables. The treatment of compost fertilizer dosage have no significant to effect foe leaf number and dry weight of oven fruit, but it had significant effect to the weight of fresh and dried weight of oven stover and very significant effect on the variables of plant height, the number of fruit and the weight of fresh fruit. The dosage of compost fertilizer 8 ton ha-1 to got the highest fresh weight of fruit per plant which is 380, $42 \mathrm{~g}$, an increase of 44,05\% if compared with the lowest fresh fruit weight per plant obtained in the treatment without compost 0 tons ha- ${ }^{l}$ of $264.08 \mathrm{~g}$. The results of the distribution of NPK Phonska at different doses have no significant effect on one another. However, , the highest fresh fruit weight was obtained at NPK treatment at $400 \mathrm{~kg}$ ha-1 treatment ie $351,75 \mathrm{~g}$. This increased by $7.02 \%$ when compared with the freshest weight of lowest fruit obtained at $200 \mathrm{~kg}$ ha-1 treatment ie $328,67 \mathrm{~g}$.
\end{abstract}

\section{Keywords: Okra plant, compost and NPK phonska}

\section{Pendahuluan}

Okra (Abelmoschus esculentus) merupakan tanaman sayuran yang tumbuh di daerah tropis dan bagian sub-tropis di dunia. Di Indonesia khususnya di Bali tanaman ini belum begitu dikenal atau masih langka, hanya terdapat di supermarket besar. Di beberapa tempat Okra di kenal dengan nama berbeda ada yang menyebutnya Okura, kacang bendi ataupun Lady Finger. Tanaman ini sudah dibudidayakan sangat populer di negara-negara Asia seperti Jepang, Malaysia, Cina dan India. India menempati urutan pertama di dunia dengan 3,5 juta ton ( $70 \%$ dari total produksi dunia) dari okra dihasilkan dari lebih dari 0.350.000 ha lahan (Frank, 2009).

Buah okra mempunyai kandungan gizi yang tinggi, kaya serat, antioksidan dan vitamin C. Oleh karena itu buah okra banyak dikonsumsi baik sebagai sayur maupun sebagai obat karena buah okra dapat memberi manfaat positif bagi tubuh dalam menjaga kesehatan. Buah okra tergolong buah yang mengeluarkan lendir karena mengandung musilane. Padahal dalam lendir itulah sebagian besar manfaat dan khasiat buah okra tersimpan. Komposisi okra buah per $100 \mathrm{~g}$ mengandung air 81,50 g, energi 235.00 $\mathrm{kJ}$ (56.00 kkal), protein 4,40 g, lemak 0,60 g, karbohidrat $11.30 \mathrm{~g}$, serat 2,10 g, Ca 532,00 mg, P 70,00 $\mathrm{mg}, \mathrm{Fe} 0.70 \mathrm{mg}$, asam askorbat $59.00 \mathrm{mg}$, betakaroten $385.00 \mathrm{mg}$, thiamin $0,25 \mathrm{mg}$, riboflavin 2,80 $\mathrm{mg}$, niacin 0,20 mg (Benchasri, 2012).

Okra menyediakan banyak nutrisi yang dibutuhkan, hampir setengahnya berupa soluble fiber dalam bentuk lendir dan peptin yang dapat membantu menurunkan kadar kolesterol dan mengurangi resiko penyakit jantung. Sisanya adalah insoluble fiber yang dapat membantu menjaga kondisi kesehatan (Adetuyi, 2011). 
Tanaman okra memiliki karakteristik pertumbuhan secara indeterminasi. Proses pembungaan selalu terjadi secara berkesinambungan tergantung atas kondisi biotik dan abiotik stress. Tanaman ini hampir selalu memunculkan bunga satu atau dua bulan setelah proses penanaman. Buahnya berbentuk seperti kapsul dan tumbuh dengan cepat setelah melalui proses pembungaan. Pertambahan maksimal dari panjang, lebar, dan diameter buah berada di kisaran antara 4 sampai 6 hari setelah proses pembungaan. Pada fase ini buah tersebut sudah dapat diambil untuk dikonsumsi. Buah okra dipanen ketikka telah matang, tetapi sebelum mulai mengering. Secara umum produksi fiber didalam buah berawal sejak hari ke 6 berdasarkan formasi buah dan mengalami kenaikan kandungan fiber mulai hari ke 9 saat diobservasi. Tanaman okra akan terus berbunga hingga berbuah dalam waktu yang tidak dapat ditentukan, tergantung atas varietasnya, musim dan keadaan tanah. Dapat diketahui bahwa pemanenan yang biasa dilakukan secara terus menerus menstimulasi tanaman untuk terus berbuah, buah yang dihasilkan akan sangat banyak sehingga sangat memungkinkan untuk dilakukan proses panen setiap hari pada wilayah dengan iklim dimana dapat mendukung pertumbuhan tanaman secara maksimal (Ministy of Environment and Forest, 2009).

Untuk meningkatkan hasil tanaman sayuran dan efisiensi biaya produksi serta meningkatkan nilai tambah maka salah satu alternatif dengan menggunakan pupuk yang tepat serta sesuai dengan kebutuhan optimal tanaman. Pupuk yang digunakan adalah perpaduan pupuk organik dan an organik.

Kompos dan humus merupakan pupuk organik dari hasil pelapukan jaringan atau bahan-bahan tanaman atau limbah organik. Menurut Djajakirana (2002) kompos didefinisikan sebagai campuran pupuk dari bahan organik yang berasal dari tanaman, hewan atau campuran keduanya yang telah terlapuk sebagian dan dapat berisi senyawa-senyawa lain seperti abu, kapur dan bahan kimia lainnya sebagai bahan tambahan.

Kompos merupakan pupuk organik yang berasal dari sisa tanaman dan kotoran hewan yang telah mengalami proses dekomposisi atau pelapukan sehingga dapat dimanfaatkan untuk memperbaiki sifatsifat tanah karena perannya yang sangat penting terhadap perbaikan sifat fisik, kimia dan biologi tanah, namun sisa hasil tanaman dan kotoran hewan tidak dikelola dengan baik maka akan berdampak negatif terhadap lingkungan, seperti mengakibatkan rendahnya keberhasilan pertumbuhan sebagai tempat berkembang biaknya patogen tanaman. Bahan-bahan ini menjadi lapuk dan busuk bila berada dalam keadaan basah dan lembab, seperti halnya daun-daun menjadi lapuk bila jatuh ke tanah dan menyatu dengan tanah. Selama perubahan dan peruraian bahan organik, unsur hara akan bebas menjadi bentuk yang larut dan dapat diserap tanaman. Sebelum mengalami proses perubahan, sisa hewan dan tumbuhan ini tidak berguna bagi tanaman karena unsur hara masih dalam bentuk terikat yang tidak dapat diserap oleh tanaman. Kompos yang baik adalah yang sudah cukup mengalami pelapukan dan dicirikan oleh warna yang sudah berbeda dengan warna bahan pembentuk dan tidak berbau (Peni dan Teguh, 2007). Pemberian dosis kompos 7,5-15 ton ha-1 dapatmeningkatkan tinggi tanaman, berat segar tongkol, dan berat segar brangkasan tanaman jagung (Situmeang et al., 2016). Pemanfaatan pupuk kompos kotoran sapi 20 ton ha-1 dan NPK phonska $300 \mathrm{~kg}$ ha-1 dapat meningkatkan pertumbuhan dan hasil tanaman jagung hibrida Bisi-2 (Situmeang et. al., 2015; Situmeang, 2017). Aplikasi kompos 20 ton ha-1 memberikan hasil tertinggi dari berat segar tanaman sayuran pakchoy, yang meningkat $44 \%$ dibandingkan hasil terendah pada pemberian tanpa kompos (Situmeang et al., 2017).

Pupuk Kompos super petani bali merupakan pupuk organik sebagai hasil dari proses biologi oleh aktivitas mikroorganisme decomposer (bakteri dan cacing) dalam menguraikan atau dekomposisi bahan organik menjadi humus. Pengomposan secara aerobik paling banyak digunakan, karena mudah dan 
murah untuk dilakukan, serta tidak membutuhkan kontrol proses yang terlalu sulit. Dekomposisi bahan dilakukan oleh mikroorganisme di dalam bahan itu sendiri dengan bantuan udara. Sedangkan pengomposan secara anaerobik memanfaatkan mikroorganisme yang tidak membutuhkan udara dalam mendegradasi bahan organik.

Pupuk NPK phonska adalah pupuk majemuk yang terdiri dari beberapa unsur hara makro yaitu, nitrogen $(\mathrm{N}) 15 \%$, phosfor $(\mathrm{P}) 15 \%$, kalium $(\mathrm{K}) 15 \%$, dan sulfur $(\mathrm{S}) 10 \%$ yang dibutuhkan oleh tanaman. Masing-masing dari unsur hara yang terdapat pada pupuk phonska memiliki peran dan fungsi yang berbeda pula. Oleh sebab itu, sebagai pupuk majemuk pupuk NPK phonska memiliki fungsi dan manfaat yang beragam pada tanaman. Sedangkan pupuk NPK phonska ini memiliki sifat-sifat antara lain sebagai berikut : (1) Pupuk phonska berbentuk granular (butiran) berwarna merah jambu/pink. (2) Bersifat higroskopis sehingga mudah larut dalam air, (3) Mudah diserap oleh tanaman, (4) Memiliki kandungan unsur hara yang lengkap.

\section{Bahan dan Metode}

Penelitian berlokasi di Kebun Percobaan Fakultas Pertanian Universitas Warmadewa , Kecamatan Sumerta, Kotamadya Denpasar, dengan ketinggian tempat 15 meter di atas permukaan laut dan suhu rata -rata $25^{\circ} \mathrm{C}-30^{\circ} \mathrm{C}$, yang dimulai bulan Mei-September 2017 .

Rancangan yang digunakan dalam penelitian ini adalah Rancangan Acak Kelompok (RAK) faktorial. Perlakuan terdiri dari dua faktor yaitu faktor pertama dosis pupuk Kompos (K) yang terdiri dari empat taraf yaitu: $\mathrm{K} 0=$ Tanpa Kompos, $\mathrm{K} 1=4$ ton ha-1, $\mathrm{K} 2=6$ ton ha- 1 dan $\mathrm{K} 3=8$ ton ha-1 dan faktor kedua adalah dosis pupuk NPK Phonska $(\mathrm{P})$ yang terdiri dari empat taraf yaitu : P0 = Tanpa NPK, P1 = $200 \mathrm{~kg}$ ha-1, P2 = $300 \mathrm{~kg}$ ha-1, dan P3 = $400 \mathrm{~kg}$ ha-1. Dengan demikian terdapat 16 perlakuan kombinasi dan masing-masing perlakuan diulangi 4 kali, sehingga terdapat 64 polybag tanaman percobaan.

Perlakuan pupuk Kompos diberikan satu kali yaitu pada saat tanam bibit, dengan cara dicampurkan didalam masing-masing polybag sesuai dengan perlakuan Sedangkan perlakuan NPK Phonska juga diberikan satu kali yaitu pada saat tanam, dengan cara tugal sesuai dengan perlakuan.

Pemeliharaan tanaman meliputi penyiraman yang dilakukan setiap hari, penyiangan dilakukan setiap ada gulma yang tumbuh dengan mencabut gulma yang ada. Okra dipanen pada umur 1,5 bulan setelah tanam. Buah okra yang siap dipanen berwarna hijau tua, lengkungan pada buah terlihat sempurna, tidak cacat, dan tidak terlalu tua.

Adapun variabel pertumbuhan dan hasil yang diamati dalam penelitian ini adalah tinggi tanaman maksimum (cm), jumlah daun per tanaman ( helai ), jumlah buah per tanaman (buah), berat segar buah per tanaman (g), berat segar brangkasan per tanaman $(\mathrm{g})$, berat kering oven buah per tanaman $(\mathrm{g})$, berat kering oven brangkasan per tanaman $(\mathrm{g})$.

Data hasil penelitian di analisis dengan analisis keragaman untuk mengetahui pengaruh perlakuan terhadap variabel yang diukur. Sedangkan, untuk mengetahui beda nyata diantara perlakuan digunakan uji BNT dengan taraf 5\%. Untuk mengetahui keeratan hubungan antar variabel yang diamati dilakukan analisis korelasi. Selanjutnya untuk mengetahui hubungan antar perlakuan yang diberikan dengan hasil yang diperoleh dilakukan analisis regresi. 


\section{Hasil dan Pembahasan}

\subsection{Hasil Penelitian}

Signifikansi peningkatan hasil tanaman okra dengan pemberian pupuk terhadap semua variabel yang diamati disajikan pada Tabel 1. Interaksi perlakuan dosis pupuk kompos dengan NPK phonska (KxP) dan perlakuan dosis pupuk NPK phonska $(P)$ berpengaruh tidak nyata $(P \geq 0,05)$ terhadap seluruh variabel yang diamati. Perlakuan dosis kompos berpengaruh tidak nyata $(\mathrm{P} \geq 0,05)$ terhadap jumlah daun dan berat kering oven buah per tanaman, berpengaruh nyata $(\mathrm{P}<0,05)$ terhadap berat segar dan berat kering oven brangkasan serta berpengaruh sangat nyata $(\mathrm{P}<0,01)$ terhadap tinggi tanaman, jumlah buah dan berat segar buah per tanaman.

Tabel 1

Signifikansi Peningkatan Hasil Tanaman Okra dengan Pemberian pupuk Kompos dan NPK phonska terhadap semua variabel yang diamati.

\begin{tabular}{|l|l|l|l|}
\hline \multirow{2}{*}{ Variabel } & \multicolumn{2}{|l|}{ Perlakuan } \\
\cline { 2 - 4 } & Kompos (K) & NPK (P) & Interaksi (KxP) \\
\hline Tinggi tanaman maksimum(cm) & $* *$ & $\mathrm{~ns}$ & $\mathrm{~ns}$ \\
\hline Jumlah daun maksimum (helai) & $\mathrm{ns}$ & $\mathrm{ns}$ & $\mathrm{ns}$ \\
\hline Jumlah buah per tanaman (buah) & $* *$ & $\mathrm{~ns}$ & $\mathrm{~ns}$ \\
\hline Berat Segar Buah per tanaman $(\mathrm{g})$ & $* *$ & $\mathrm{~ns}$ & $\mathrm{~ns}$ \\
\hline Berat Kering oven buah per tanaman $(\mathrm{g})$ & $\mathrm{ns}$ & $\mathrm{ns}$ & $\mathrm{ns}$ \\
\hline Berat segar berangkasan $(\mathrm{g})$ & $*$ & $\mathrm{~ns}$ & $\mathrm{~ns}$ \\
\hline Berat kering oven berangkasan $(\mathrm{g})$ & $*$ & $\mathrm{~ns}$ & $\mathrm{~ns}$ \\
\hline
\end{tabular}

Keterangan : ns $=$ Berpengaruh tidak nyata $(\mathrm{P} \geq 0,05)$

$* *=$ Berpengaruh sangat nyata $(\mathrm{P}<0,01)$

$* \quad=$ Berpengaruh nyata $(\mathrm{P}<0,05)$

\section{Jumlah daun maksimum}

Rata-rata jumlah daun maksimum tertinggi diperoleh pada dosis tanpa kompos 0 ton ha ${ }^{-1}\left(\mathrm{~K}_{0}\right) 10,33$ helai yang berbeda tidak nyata dengan dosis kompos lainnya. Perlakuan NPK phonska $200 \mathrm{~kg} \mathrm{ha}^{-1}\left(\mathrm{P}_{1}\right)$ memberikan jumlah daun maksimum tertinggi sebanyak 9,58 helai, yang berbeda tidak nyata dengan perlakuan NPK phonska lainnya.

\section{Jumlah Buah}

Jumlah buah per tanaman tertinggi didapat pada perlakuan pupuk kompos 8 ton ha ${ }^{-1}\left(\mathrm{~K}_{3}\right)$ yaitu 20,83 buah dan jumlah buah per tanaman terendah didapat pada 0 ton ha ${ }^{-1}\left(\mathrm{~K}_{0}\right)$ 15,42 buah. Pemberian dosis NPK phonska menyebabkan jumlah buah per tanaman meningkat, tertinggi didapat pada perlakuan NPK phonska $400 \mathrm{~kg} \mathrm{ha}^{-1}\left(\mathrm{P}_{3}\right)$ yaitu 19,58 buah yang berbeda tidak nyata dengan perlakuan lainnya.

\section{Berat Segar Buah per tanaman}

Berat segar buah per tanaman tertinggi diperoleh pada perlakuan pupuk kompos 8 ton ha ${ }^{-1}\left(\mathrm{~K}_{2}\right)$ yaitu $380,42 \mathrm{~g}$ dan berat segar buah per tanaman terendah didapat pada 0 ton $\mathrm{ha}^{-1}\left(\mathrm{~K}_{0}\right)$ yaitu $264,08 \mathrm{~g}$. Berat segar buah per tanaman tertinggi diperoleh pada perlakuan NPK $400 \mathrm{~kg} \mathrm{ha}^{-1}$ (P3) yaitu 351,75 $\mathrm{g}$ yang 
berbeda tidak nyata dengan perlakuan lainnya.

\section{Berat Segar Brangkasan}

Berat segar brangkasan tertinggi diperoleh pada perlakuan pupuk kompos 8 ton ha ${ }^{-1}\left(\mathrm{~K}_{2}\right)$ yaitu 360,92 g yang berbeda nyata dengan perlakuan lainnya. Berat segar brangkasan tertinggi diperoleh pada perlakuan NPK $200 \mathrm{~kg} \mathrm{ha}^{-1}\left(\mathrm{P}_{1}\right)$ yaitu 328,50 g yang berbeda tidak nyata dengan perlakuan lainnya.

\section{Berat Kering Oven Buah per tanaman}

Berat kering oven buah tertinggi diperoleh pada perlakuan pupuk kompos 8 ton ha ${ }^{-1}\left(\mathrm{~K}_{2}\right)$ yaitu 30,58 $\mathrm{g}$ yang berbeda tidak nyata dengan perlakuan lainnya, terendah diperoleh pada perlakuan 0 ton ha ${ }^{-1}\left(\mathrm{~K}_{0}\right)$ yaitu 23,50 g. Berat kering oven buah tertinggi diperoleh pada perlakuan NPK $400 \mathrm{~kg} \mathrm{ha}^{-1}\left(\mathrm{P}_{3}\right)$ yaitu $29,17 \mathrm{~g}$ yang berbeda tidak nyata dengan perlakuan lainnya.

\section{Berat Kering Oven Brangkasan}

Berat kering oven brangkasan tertinggi diperoleh pada perlakuan pupuk kompos 8 ton ha ${ }^{-1}\left(\mathrm{~K}_{2}\right)$ yaitu $53,17 \mathrm{~g}$. Berat kering oven brangkasan tertinggi diperoleh pada perlakuan NPK phonska $200 \mathrm{~kg} \mathrm{ha}^{-1}\left(\mathrm{P}_{1}\right)$ yaitu $48,95 \mathrm{~g}$ yang berbeda tidak nyata dengan perlakuan lainnya.

\subsection{Pembahasan}

Interaksi antara dosis pupuk kompos dengan NPK phonska berpengaruh tidak nyata terhadap seluruh variabel yang diamati, sehingga belum didapatkan kombinasi yang tepat untuk meningkatkan hasil tanaman okra. Pemberian pupuk kompos dapat meningkatkan berat segar buah per tanaman pada tanaman okra. Berat segar buah per tanaman tertinggi diperoleh pada perberian dosis pupuk kompos 8 ton ha ${ }^{-1}\left(\mathrm{~K}_{2}\right)$ yaitu 380,42 g yang berbeda tidak nyata dengan perlakuan 4 ton ha ${ }^{-1}\left(\mathrm{~K}_{1}\right)$ dan 6 ton ha ${ }^{-1}\left(\mathrm{~K}_{2}\right)$ dengan nilai berturut-turut 343,92 $\mathrm{g}$ dan 363,42 $\mathrm{g}$ atau mengalami peningkatan sebesar 44,05\% bila dibandingkan dengan berat segar buah terendah yang di peroleh pada perlakuan tanpa dosis kompos 0 ton ha ${ }^{-1}\left(\mathrm{~K}_{0}\right)$ yaitu $264,08 \mathrm{~g}$.

Tingginya berat segar buah per tanaman pada perlakuan pupuk kompos 8 ton ha ${ }^{-1}\left(\mathrm{~K}_{2}\right)$ didukung oleh variabel tinggi tanaman $\left(\mathrm{r}=0,99^{* *}\right)$, jumlah daun $\left(\mathrm{r}=0,76^{* *}\right)$, jumlah buah $\left(\mathrm{r}=0,96^{* *}\right)$, berat segar berangkasan $\left(\mathrm{r}=0,97^{* *}\right)$, berat kering oven buah $\left(\mathrm{r}=0,96^{* *}\right)$ dan berat kering oven brangkasan $(\mathrm{r}=$ $\left.0,69^{* *}\right)$. Tingginya berat segar buah per tanaman pada perlakuan pupuk kompos 8 ton ha ${ }^{-1}$, disebabkan karena membaiknya sifat fisik tanah atau kesuburan tanah secara keseluruhan akibat pemberian kompos. Kondisi ini dapat dilihat dari pertumbuhan bagian vegetatif tanaman yang lebih tinggi seperti tinggi tanaman maksimum dan jumlah daun serta dilihat dari berat segar dan berat kering oven brangkasan pada pemberian dosis pupuk kompos 8 ton $\mathrm{ha}^{-1}$, dengan membaiknya pertumbuhan vegetatif tanaman ini menyebabkan meningkatnya intersepsi cahaya matahari oleh daun untuk menghasilkan fotosintat dan dalam perkembangan selanjutnya fotosintat ini akan ditransfer keorgan-organ tanaman yang aktif mengadakan proses metabolisme sehingga pertumbuhan akar, batang dan daun tanaman menjadi lebih baik dan selanjutnya akan mempengaruhi hasil ekonomi tanaman yaitu jumlah buah dan berat segar buah per tanaman. Kompos merupakan bahan organik yang telah mengalami dekomposisi oleh 
mikroorganisme pengurai sehingga dapat dimanfaatkan untuk memperbaiki sifat-sifat tanah, disamping itu di dalam kompos terkandung hara-hara mineral yang berfungsi untuk penyediaan makanan bagi tanaman. Selain itu, kompos juga dapat memperbaiki sifat fisik tanah sehingga tanah menjadi remah dan pada gilirannya mikroba-mikroba tanah yang bermanfaat dapat hidup lebih subur.

Tabel 11.

Nilai Koefisien Korelasi Antar Variabel Tanaman (R) karena Pengaruh Dosis Kompos

Tabel 11.

Nilai Koefisien Korelasi Antar Variabel Tanaman (R) karena Pengaruh Dosis Kompos

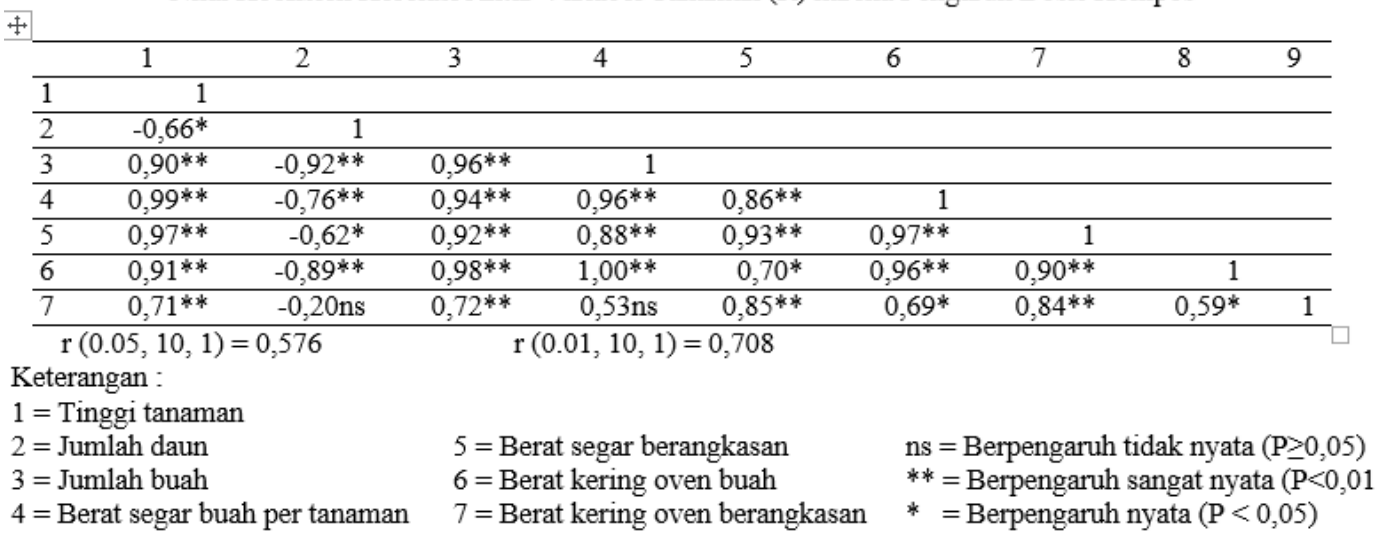

Hasil analisis regresi hubungan antara perlakuan dosis pupuk kompos dengan berat segar buah per tanaman menunjukkan hubungan yang linier dengan persamaan : $\hat{Y}=17,46+0,06498 X$ yang berarti belum didapatkan dosis kompos yang optimum dimana peningkatan dosis pupuk kompos melebihi 8 ton $\mathrm{ha}^{-1}$ masih dapat meningkatkan berat segar buah per tanaman (Gambar 1.)

Berat segar buah tertinggi diperoleh pada perlakuan NPK $400 \mathrm{~kg} \mathrm{ha}^{-1}$ (P3) yaitu 351,75 g yang berbeda tidak nyata dengan perlakuan lainnya, mengalami peningkatan sebesar $7,02 \%$ bila dibandingkan dengan berat segar buah terendah diperoleh pada $200 \mathrm{~kg} \mathrm{ha}^{-1}\left(\mathrm{P}_{0}\right)$ yaitu 328,67 $\mathrm{g}$.

Fitted Line Plot

$\mathrm{Y}=17,46+0,06498 \mathrm{X}$

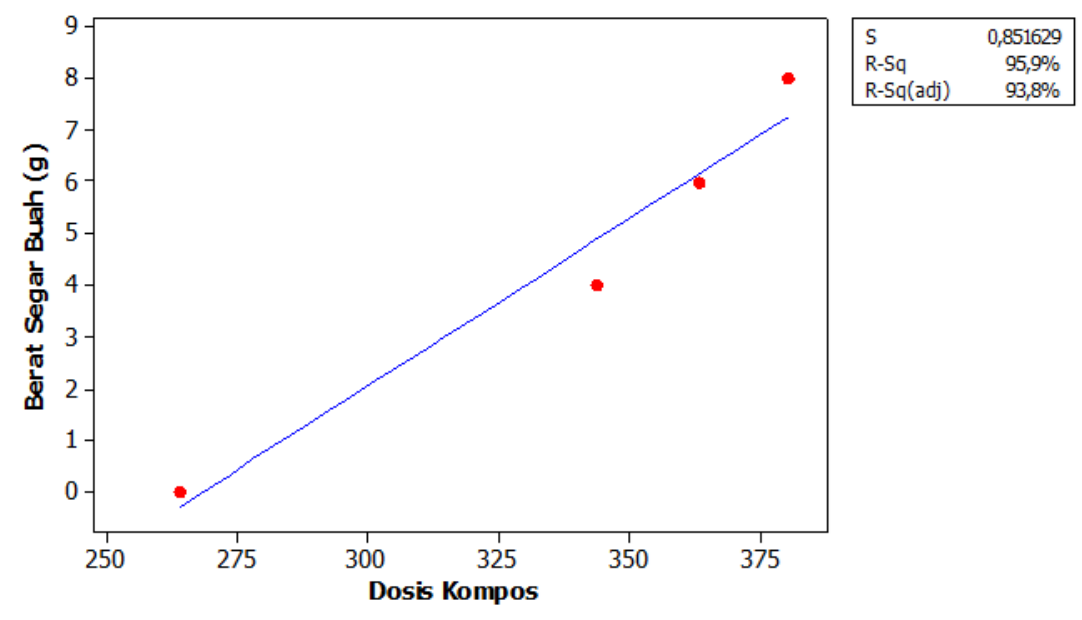

Gambar 1

Hubungan pupuk kompos dengan berat segar buah per tanaman. 


\section{Kesimpulan}

Perlakuan interaksi antara dosis pupuk kompos dengan NPK phonska maupun perlakuan tunggal NPK phonska berpengaruh tidak nyata terhadap seluruh variabel yang diamati. Perlakuan dosis pupuk kompos berpengaruh tidak nyata terhadap jumlah daun dan berat kering oven buah, berpengaruh nyata terhadap berat segar dan berat kering oven brangkasan dan berpengaruh sangat nyata terhadap variabel tinggi tanaman, jumlah buah dan berat segar buah. Pemberian dosis pupuk kompos 8 ton ha ${ }^{-1}$ mendapatkan berat segar buah per tanaman tertinggi yaitu 380,42 g, mengalami peningkatan sebesar $44,05 \%$ bila dibandingkan dengan berat segar buah per tanaman terendah yang di peroleh pada perlakuan tanpa pupuk kompos yaitu 264,08 g. Pemberian NPK phonska pada beberapa taraf dosis berbeda tidak nyata, namun berat segar buah tertinggi diperoleh pada perlakuan NPK $400 \mathrm{~kg} \mathrm{ha}^{-1}$ yaitu $351,75 \mathrm{~g}$, mengalami peningkatan sebesar 7,02\% bila dibandingkan dengan berat segar buah terendah diperoleh pada $200 \mathrm{~kg} \mathrm{ha}^{-1}$ yaitu $328,67 \mathrm{~g}$.

\section{Referensi}

Adetuyi (2011), Pertumbuhan dan Hasil Tanaman Okra (Abelmoschus esculantus) Dekaform dan Defoliasi. Dekaform Tablet, Defoliation, Okra, 10: (1) 10-15

Benchasri. S. (2012). Okra (Abelmoschus esculentus L. Moench) as a Valuable Vegetable of the World. Ratar.Povrt. 49 (10) : 105-112.

Djajakirana, G. (2002). Proses Pembuatan, Pemanfaatan dan Pemasaran Vermi kompos untuk Pertanian di Indonesia. Makalah disampaikan pada Seminar "Pemanfaatan Teknologi Aplikatif Pertanian dalam Mencapai Suatu Pertanian Berkelanjutan" - "Planolgi A Plus 2002" - Bogor, 12 Mei 2002.

Frank. S. (2009). Biology of Okra. India : Department of Biotechnology.

Ministy of Environment and Forest (2009). Biology of Okra. India : Department of Biotechnology

Peni, W. P. \& Teguh, P. (2007). Petunjuk Teknis Pembuatan Kompos Berbahan Kotoran Sapi. Pusat Penelitian dan Pengembangan Peternakan. Pasuruan.

Situmeang, Y. P., Adnyana, I. M., Subadiyasa, I. N. N., \& Merit, I. N. (2015). Effect of Dose Biochar Bamboo, Compost, and Phonska on Growth of Maize (Zea mays L.) in Dryland. International Journal on Advanced Science, Engineering and Information Technology, 5(6), 433-439.

Situmeang, Y.P., Sudewa, K.A. Suarta, M., \& Andriani, A.A.S. R. (2016). Biochar and Compost Effect on the Growth and Yield of Sweet Corn. Gema Agro, (16)36, 16-19.

Situmeang, Y. P. (2017). Utilization of Biochar, Compost, and Phonska in Improving Corn Results on Dry Land. International Research Journal of Engineering IT and Scientific Research, 3(3): 38-48.

Situmeang, Y.P., Sudewa, K.A., \& Holo, P.P. (2017). Utilization Biochar of Bamboo and Compost in Improving Yield of Pakchoy Plant. Journal of Biological and Chemical Research, 34(2): 713-722. 